THE UNDERGROUND WEALTH OF NATIONS 
YALE SERIES IN ECONOMIC AND FINANCIAL HISTORY

Sponsored by the International Center for Finance, Yale School of Management

\section{General Editors}

Howard Bodenhorn

Clemson University, Department of Economics

William N. Goetzmann

Yale University, School of Management

K. Geert Rouwenhorst

Yale University, School of Management

Eugene N. White

Rutgers University, Department of Economics 


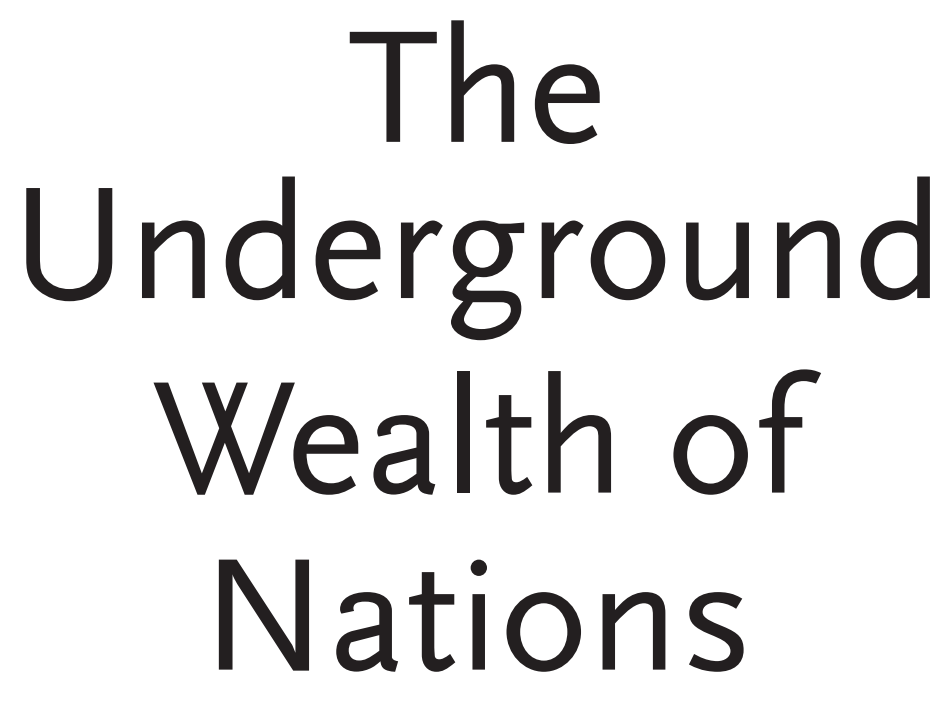

ON THE CAPITALIST ORIGINS

OF SILVER MINING,

A.D. $1150-1450$

Yale

UNIVERSITY PRESS

NEW HAVEN \& LONDON 
Published with assistance from the Louis Stern Memorial Fund.

Copyright (C) 2019 by Jeannette Graulau. All rights reserved. This book may not be reproduced, in whole or in part, including illustrations, in any form (beyond that copying permitted by Sections 107 and 108 of the U.S.

Copyright Law and except by reviewers for the public press), without written permission from the publishers.

Yale University Press books may be purchased in quantity for educational, business, or promotional use. For information, please e-mail sales.press@yale.edu (U.S. office) or sales@yaleup.co.uk (U.K. office).

Set in Times Roman type by Integrated Publishing Solutions, Grand Rapids, Michigan.

Printed in the United States of America.

Library of Congress Control Number: 2019937183

ISBN 978-0-300-21822-0 (hardcover : alk. paper)

A catalogue record for this book is available from the British Library.

This paper meets the requirements of ANSI/NISO Z39.48-1992 (Permanence of Paper).

$1099876 \begin{array}{lllll}6 & 4 & 3 & 2 & 1\end{array}$ 
To Arístides Rodríguez Rivera

and José Pepe González Díaz, with admiration, and Luis Vázquez González, in memoriam 
This page intentionally left blank 